\title{
Clinical Characterisation of Wilson's Disease Patients and Predictors of Neurological Involvement: A Retrospective Study at a Tertiary Care Centre in Lisbon
}

\author{
Caracterização Clínica de Doentes com Doença de Wilson e Preditores de \\ Envolvimento Neurológico: Estudo Retrospetivo num Centro Terciário em Lisboa
}

\author{
D José Lourenço Rosa ${ }^{1, *}$, Ary de Sousa ${ }^{2}$, Pedro Brás ${ }^{3}$, Manuel Machado ${ }^{1}$, Margarida Dias ${ }^{1}$, Manuel Manita ${ }^{1}$ \\ 1-Neurologia / Centro Hospitalar Universitário de Lisboa Central, Lisboa, Portugal \\ 2-Serviço de Neurologia / Centro Hospitalar Universitário de Lisboa Central, Hospital de Vila Franca de Xira, Vila Franca de Xira, Portugal \\ 3-Serviço de Neurologia / Centro Hospitalar Universitário de Lisboa Central, Centro Hospitalar de Leiria, Leiria, Portugal
}

DOI: https://doi.org/10.46531/sinapse/AO/210033/2021

\section{Abstract}

Introduction: Wilson's disease (WD) is an autosomal recessive metabolic disorder caused by ATP7B gene mutations, producing toxic copper accumulation, mainly in the liver and the brain. We aim to characterise the population of patients with WD followed at our centre and to identify possible factors that may correlate with neurological involvement in WD.

Methods: We identified all patients with the diagnosis of WD listed in our centre's database between 2009 and 2017. We reviewed case records and collected clinical, laboratorial, genetic and imaging data.

Results: We identified 24 patients, 17 (71\%) of which were females. The median age at diagnosis was 17 years. ATP7B gene sequencing result reported c.2123T>C as the most frequent mutation. The mixed hepatic and neurological presentation was the most common form $(45.8 \%, 11$ cases). Pure hepatic and neurological presentations were found in 10 (41.7\%) and 3 (12.5\%) patients, respectively. Rigidity, bradykinesia and tremor were the most reported neurological signs, with bradykinesia being more frequent in the younger patients. Normal liver transaminase levels at diagnosis correlated with the presence of neurological disease $(p<0.01)$. Six patients with neurological symptoms presented brain magnetic resonance imaging changes compatible with WD. Follow-up reported improvement with treatment in 8/11 (73\%) patients with neurological symptoms.

Conclusion: Initial assessment of liver transaminase levels may help to identify WD patients who are more likely to develop in time neurological symptoms, alerting to the need for regular neurological evaluations.

\section{Resumo}

Introdução: A doença de Wilson (DW) é uma perturbação metabólica autossómica recessiva causada por mutações do gene ATP7B que conduz a acumulação tóxica de cobre, sobretudo no fígado e cérebro. Pretendemos caracterizar a população de doentes com DW seguidos no nosso centro hospitalar e identificar possíveis fatores que possam relacionar-se com o envolvimento neurológico na DW.

Métodos: Identificámos todos os doentes com diagnóstico de DW presentes na base de dados do nosso centro hospitalar entre 2009 e 2017. Revimos registos clínicos e colhemos dados clínicos, laboratoriais, genéticos e imagiológicos.
Informações/Informations: Artigo Original, publicado em Sinapse, Volume 21, Número

3, julho-setembro 2021. Versão eletrónica em www.sinapse.pt Original Article, published in

Sinapse, Volume 21, Number

3, July-September 2021.

Electronic version in www

sinapse.pt

(C) Autor (es) (ou seu (s) empregador (es)) e Sinapse 2021. Reutilização permitida de acordo com CC BY-

NC. Nenhuma reutilização comercial.

(C) Author(s) (or their employer(s)) and Sinapse 2021

Re-use permitted under CC BYNC. No commercial re-use.

\section{Keywords:}

Hepatolenticular Degeneration; Neurologic Manifestations; Nervous System Diseases.

Palavras-chave:

Degeneração Hepatolenticular; Doenças do Sistema Nervoso; Manifestações Neurológicas.

\section{*Autor Correspondente / Corresponding Author: José Lourenço Rosa Serviço de Neurologia Centro Hospitalar Universitário de Lisboa Central Alameda Santo António dos Capuchos \\ 1169-050 Lisboa, Portugal jlourencorosa@gmail.com}

Recebido / Received: 2021-05-16 Aceite / Accepted: 2021-08-11 Publicado / Published: 2021-10-20 
Resultados: Identificámos 24 doentes, 17 (71\%) deles do género feminino. A idade mediana no diagnóstico foi de 17 anos. A sequenciação do gene ATP7B evidenciou a mutação c.2123T>C como a mais frequente. A forma de apresentação mista (hepática e neurológica) foi a mais comum (45,8\%, 11 casos). As formas de apresentação puras hepática e neurológica foram encontradas em $10(41,7 \%)$ e 3 $(12,5 \%)$ doentes, respetivamente. Rigidez, bradicinesia e tremor foram os sinais neurológicos mais frequentes, sendo a bradicinesia mais frequente em indivíduos mais jovens. A presença de transaminases hepáticas em valores normais no momento do diagnóstico relacionou-se com a presença de doença neurológica $(p<0,01)$. Seis doentes com sintomas neurológicos apresentaram alterações na RM-CE compatíveis com DW. Ocorreu melhoria com o tratamento em 8 (73\%) dos doentes com sintomas neurológicos.

Conclusão: $O$ doseamento das transaminases hepáticas pode ajudar a identificar doentes com DW que desenvolvam mais provavelmente sintomas neurológicos, alertando para a necessidade de avaliações neurológicas regulares.

\section{Introduction}

First identified by Kinnear Wilson in 1912,1,2 Wilson's disease (WD) is a monogenic autosomal recessive disorder caused by pathogenic variants in the coppertransporting gene ATP7B and results in hepato-cellular copper deposition. ${ }^{3}$ The overall estimated prevalence is between I:30 000 and I:40 000 with a carrier frequency of $1: 90$ to $1: 100.4,5$ The country with the highest incidence in the world is Costa Rica (4.9:100 000 inhabitants). ${ }^{2}$

Until now, ATP7B has been the only identified gene known to cause WD. ${ }^{6}$ It is located on chromosome $|3 q| 4-\left.2\right|^{1,6}$ and contains 20 introns and $2 \mid$ exons, for a total genomic length of $80 \mathrm{~kb} .^{6}$ There are more than 600 known pathogenic variants in the ATP7B gene and the most common types are single-nucleotide missense and nonsense mutations. ${ }^{6}$ The most common mutation in Europe and North America is p.H1069Q (c.3207C>A). ${ }^{1,2,4,6}$

ATP7B is a copper transporting ATPase and is most highly expressed in the liver. It is also present in the kidney, placenta, mammary glands, brain, and lung. ${ }^{5,6} A T P 7 B$ has two functions within the hepatocytes: I) it activates ceruloplasmin in the trans-Golgi network by packing six copper molecules into apoceruloplasmin to be secreted into plasma and 2) it sequesters excess cytoplasmic copper into vesicles, excreting it via exocytosis into bile., The precise role of copper in the pathophysiology of WD remains not completely understood, ${ }^{7}$ but free cop- per has presumably two main toxic mechanisms: direct oxidative stress and unregulated apoptosis. ${ }^{2,5}$

Although the liver is the most affected organ in WD, ${ }^{5}$ clinical manifestations also include nervous system disease, osteoporosis, and Kayser-Fleischer rings (I). Initial manifestations are hepatic in $\sim 40 \%$ of patients, neurological in $\sim 40 \%-50 \%$, and psychiatric in $\sim 10 \%$ of them. About $10 \%$ of patients are asymptomatic at diagnosis. Pure hepatic forms are more common in women. ${ }^{4}$

Neurological involvement includes involuntary movements, dystonia, tremor, bradykinesia, rigidity, gait impairment, and oropharyngeal dysfunction (dysphonia). Speech difficulties are the most common neurological manifestation, appearing in the early stages. ${ }^{1,4}$ There is no direct genotype-phenotype correlation in WD. ${ }^{6}$

It is recommended to assess ceruloplasmin plasma levels as the first step in the diagnosis of WD. Serumfree copper, liver copper content, and 24-hour urine copper assays may also be required. ${ }^{2,4}$ However, the current gold standard for WD diagnosis is direct sequencing of the ATP7B gene. ${ }^{1,6}$

The most frequent WD radiological findings on brain magnetic resonance imaging (MRI) are generally nonspecific and are characterized by bilateral hypointense lesions on $\mathrm{TI}$-weighted sequences and hyperintense lesions on T2-weighted sequences in the caudate nucleus, thalamus, midbrain, pons, and cerebellum. ${ }^{1,4}$ The characteristic hyperintense signal in the midbrain around the red nucleus and substantia nigra is responsible for the 
"panda sign". ${ }^{4}$ These findings can subside after treatment, so MRI can play a useful role in monitoring treatment effectiveness.'

Diagnosis and treatment must be promptly established. ${ }^{2}$ Treatment outcomes are better if therapy is started within one month of first symptoms. ${ }^{4}$ Treatment is based on the removal of copper excess using chelating agents such as penicillamine, trientine, or tetrathiomolybdate or by intestinal copper absorption blockage with zinc salts. ${ }^{2}$

Liver disease control is easier to achieve when compared to neurological disease and chelators have a greater effect on the liver than on the brain. ${ }^{8}$ This difference may be partly due to the paradoxical neurological exacerbation, sometimes irreversible, that may take place at treatment initiation. ${ }^{3}$ This may be caused by excessive copper chelation or poor effectiveness of intracerebral chelation. ${ }^{9}$

Prognosis is normally excellent provided treatment compliance is satisfactory. Without treatment, disease deteriorates progressively, leading to death due to liver or neurological disease. ${ }^{2}$ However, treatment in neurological WD does not always lead to a good prognosis and may even cause disease worsening. ${ }^{10}$

In this study, we aimed to characterise the population of patients with WD followed at our centre and tried to address possible factors that may correlate with neurological involvement in WD at disease diagnosis.

\section{Material and Methods}

This was a retrospective single-centre study carried out at Centro Hospitalar Universitário de Lisboa Central (Lisbon, Portugal). We identified all adult patients with the diagnosis of WD and with follow-up at the outpatient department or who were admitted at Neurology and/or Gastroenterology wards between 2009 and 2017 through our centre's clinical database. WD diagnosis was based on a combination of clinical, laboratorial, and radiological parameters and according to the European Association for Study of Liver's Clinical Practice Guidelines" ': abnormal copper/copper metabolism measurements, presence of Kayser-Fleischer ring, genetic sequencing, and/or MRI findings.

We collected the following demographic, clinical, laboratorial, and radiological data at disease diagnosis (when available): age, sex, mutated ATP7B gene variant, pharmacological treatment (copper chelating therapy and symptomatic treatment), post-treatment status in patients with neurological involvement and information regarding disease worsening, hepatic or neurological involvement, liver transplant, neurological signs and symptoms which prompted diagnosis suspicion, presence of Kayser-Fleischer ring assessed by an Ophthalmologist, presence of other diseases, median liver stiffness value on transient elastography $\left(\right.$ Fibroscan $\left.{ }^{\circledR}\right)$, presence of normal serum aspartate aminotransferase (AST) and alanine aminotransferase (ALT) levels, serum copper and ceruloplasmin levels, 24 hours urinary copper levels, copper levels in dry liver biopsy, presence of thrombocytopenia, abnormal international normalised ratio (INR) and hypoalbuminemia and MRI findings. We used global disability's motor item of Global Assessment Scale for Wilson's Disease (GAS for WD) to assess motor disability in M0 (asymptomatic or normal), MI (subtle clinical signs), M2 (difficulty in activities of daily living but independent), M3 (requires help in activities of daily living), M4 (dependent on others for activities of daily living) and M5 (bed bound). The study was conducted under the approval of the Ethics Committee of our centre and due to its retrospective nature, a waiver of consent of patients was obtained, warranting complete protection of patients' data.

We defined hepatic involvement as the presence of elevated liver enzymes (AST and/or ALT) in the blood, abnormal echographic findings, and/or abnormal liver biopsy findings at disease diagnosis or later. We also defined neurological involvement as the presence of neurological symptoms described by the assistant physician in clinical records at disease diagnosis or later. MRI findings were classified as characteristic (when typical bilateral hypointensities on TI-weighted images and hyperintensities on T2-weighted images in the caudate nucleus, thalamus, midbrain, pons, and cerebellum were present) or as uncharacteristic (when none of the previous findings was present).

We performed statistical analysis with commercially available SPSS software (version 25 for Windows, IBM Analytics, Amonk, USA). Statistical significance was assessed with a $p$-value $<0.05$. Mann-Whitney test was applied to compare medians between groups of interval dependent variables and Fisher's exact test for categorical dependent variables. 


\section{Results}

\section{Demographic characteristics (Table 1)}

We identified a total of 24 patients, 29\% $(n=7)$ of them males and $71 \%(n=17)$ of them females. The global median age at diagnosis was 17 years. The median age at diagnosis for pure hepatic form was 16.5 years, whereas the median age at diagnosis for pure neurological form was 16 years. The median age at diagnosis for mixed hepatic and neurological form was 32 years.

\section{General disease characteristics (Table 1)}

The most frequently reported ATP7B gene mutation was c. $2123 T>C$. The mixed hepatic and neurologi- cal presentation was the most common form $(45.8 \%$, II cases). Pure hepatic and neurological presentations were found in 10 (4I.7\%) and 3 (12.5\%) patients, respectively. Acute hepatic failure was the first disease manifestation in 2 patients with pure hepatic disease. Only I patient underwent a liver transplant.

\section{Neurological disease (Table 2)}

Patients with neurological symptoms were older at diagnosis than patients with only hepatic disease (29 vs 17 years), although without statistical significance $(p=0.06)$. Rigidity, bradykinesia, and tremor were the most reported neurological signs, with bradykinesia being more fre-

Table 1. General disease characteristics.

\begin{tabular}{|c|c|c|c|c|c|c|c|}
\hline $\mathbf{N}$ & Age & Sex & Gene variant & $\begin{array}{c}\text { Hepatic } \\
\text { involvement }\end{array}$ & $\begin{array}{l}\text { Neurological } \\
\text { involvement }\end{array}$ & $\begin{array}{l}\text { Psychiatric } \\
\text { involvement }\end{array}$ & $\begin{array}{l}\text { Liver } \\
\text { transplant }\end{array}$ \\
\hline 1 & 35 & $\mathrm{~F}$ & a) & $x$ & & & \\
\hline 2 & 61 & $\mathrm{~F}$ & a) & $x$ & $x$ & & \\
\hline 3 & 26 & $\mathrm{~F}$ & $\begin{array}{c}\text { c. } 3451 C>T, c .3694 A>C \\
\text { and IVS } 2+5 G>T\end{array}$ & $x$ & & & \\
\hline 4 & 55 & $M$ & a) & $x$ & $x$ & & \\
\hline 5 & 34 & $\mathrm{~F}$ & c. $3955 \mathrm{C}>\mathrm{T}^{\star}$ & $x$ & $x$ & & \\
\hline 6 & 37 & $\mathrm{~F}$ & a) & $x$ & $x$ & & \\
\hline 7 & 30 & M & c. $2333 \mathrm{G}>\mathrm{T}^{*}$ & & $x$ & & \\
\hline 8 & 56 & $\mathrm{~F}$ & c. $1612 \mathrm{C}>\mathrm{T} ;$ c c. $2123 \mathrm{~T}>\mathrm{C}$ & $x$ & $x$ & & \\
\hline 9 & 34 & $\mathrm{~F}$ & a) & $x$ & & & \\
\hline 10 & 38 & M & a) & $x$ & & & \\
\hline 11 & 18 & $\mathrm{~F}$ & a) & & $x$ & $x$ & \\
\hline 12 & 17 & M & a) & $x$ & & & \\
\hline 13 & 17 & $\mathrm{~F}$ & a) & $\begin{array}{c}\text { X (Acute hepatic } \\
\text { failure) }\end{array}$ & & & \\
\hline 14 & 52 & $\mathrm{~F}$ & c. $2123 T>C ; c .4049 T>C$ & $x$ & $x$ & & \\
\hline 15 & 21 & $\mathrm{~F}$ & a) & $\begin{array}{l}\text { X (Acute hepatic } \\
\text { failure) }\end{array}$ & & & \\
\hline 16 & 27 & $\mathrm{M}$ & c.3402delC; c.3809A>G & $x$ & $x$ & $x$ & \\
\hline 17 & 72 & $\mathrm{~F}$ & a) & $x$ & $x$ & & \\
\hline 18 & 29 & $\mathrm{~F}$ & a) & $x$ & & & \\
\hline 19 & 54 & $\mathrm{~F}$ & c. $2069 \mathrm{C}>\mathrm{T} ;$ c c. $2123 \mathrm{~T}>\mathrm{C}$ & & $x$ & & \\
\hline 20 & 38 & $\mathrm{~F}$ & a) & $x$ & $x$ & $X$ & $x$ \\
\hline 21 & 22 & $\mathrm{~F}$ & c. $2153 C>A ;$ c. 3402 delC & $x$ & & & \\
\hline 22 & 35 & M & a) & $x$ & & & \\
\hline 23 & 25 & $\mathrm{M}$ & a) & $x$ & $x$ & $x$ & \\
\hline 24 & 72 & $\mathrm{~F}$ & c.2123T>C; c.1-?_51+?del & $x$ & $x$ & & \\
\hline
\end{tabular}


Table 2. Characteristics of patients with neurological disease.

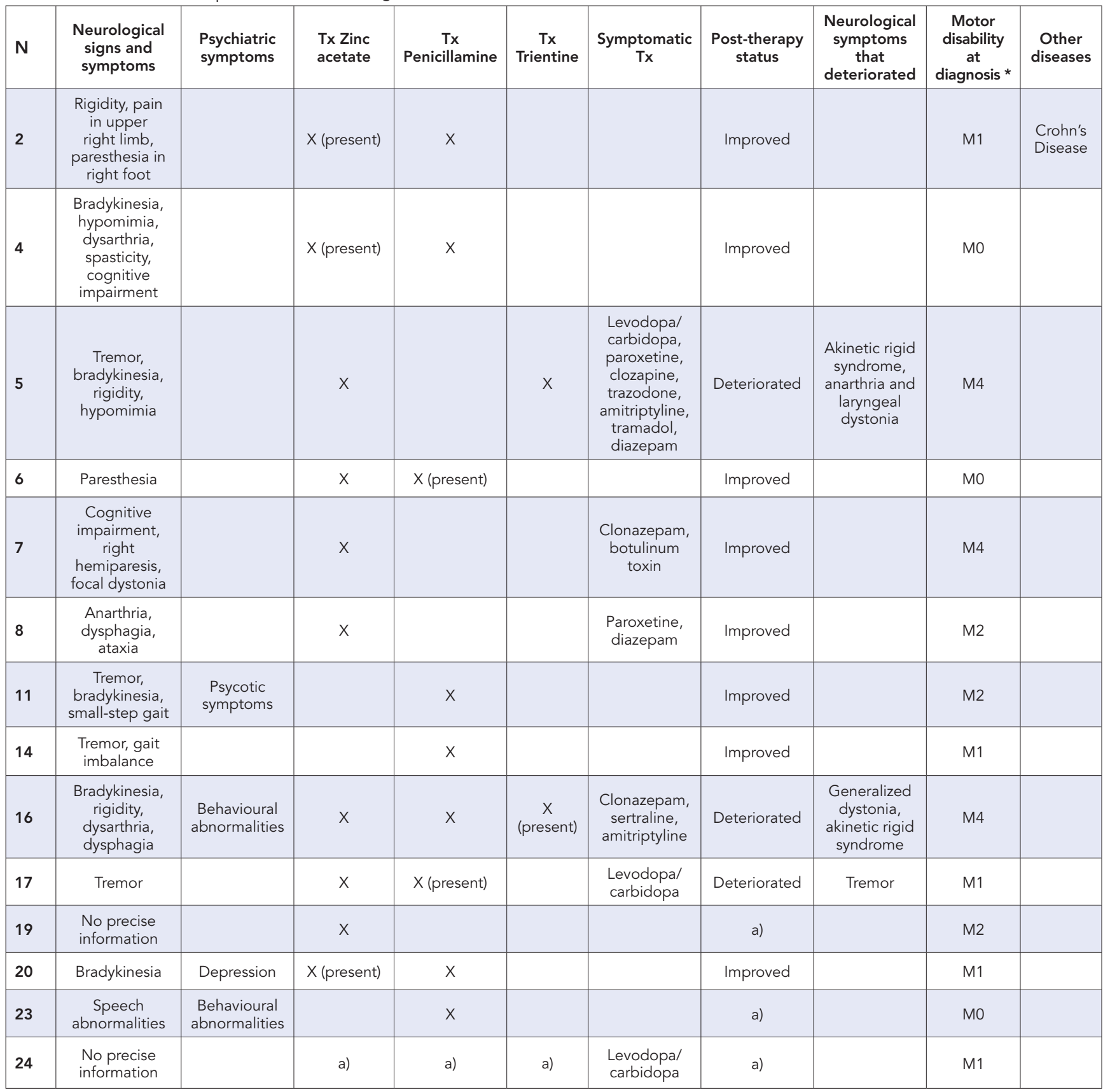

M: male; F: female; Tx: treatment with; (present): current treatment; $X$ : present; ${ }^{*}$ : according to classification of global disability's motor item of Global Assessment Scale for Wilson's Disease.

quent in the younger patients (yet, without statistical significance). Four patients presented also with psychiatric involvement showing depression, behavioural abnormalities, and psychotic symptoms. One patient had also another comorbidity (Crohn's disease). In II patients with neurological symptoms and with post-therapy status descriptions available in clinical records, follow-up reported improvement in $73 \%(n=8)$. Most of them were treated only with zinc acetate $(45 \%, n=5)$ or with penicillamine $(18 \%, n=2)$. Only $2(18 \%)$ were treated with trienthylenetetramine and experienced deterioration of their neurological status. Neurological deterioration mainly consisted of worsening of akinetic rigid syndrome and dystonia (focal or generalized). Most symptomatic treatment was based on levodopa/carbidopa and benzodiazepines (diazepam and clonazepam). The motor impact 
was defined as subtle clinical signs (MI grade of GAS for WD) for most patients $(n=5)$, with 3 patients in each one of the remaining categories ( $M 0, M 2$, and $M 4)$.

Clinical, laboratorial and radiological parameters and their correlation with neurological disease (Table 3)

Of all the variables collected at diagnosis (age, presence of Kayser-Fleischer ring, median liver stiffness value on transient elastography (Fibroscan ${ }^{\circledR}$ ), serum aspartate aminotransferase (AST) and alanine aminotransferase (ALT) levels, serum copper and ceruloplasmin levels, 24 hours urinary copper levels, copper levels in dry liver biopsy, presence of thrombocytopenia, abnormal INR and hypoalbuminemia), only normal liver transaminase levels (AST and ALT) in blood at diagnosis correlated with the presence of neurological disease $(p<0.0 \mathrm{I})$. Twelve patients had available brain MRI data, $75 \%(n=9)$ of them with neurological disease and $25 \%(n=3)$ with no neurological symptoms. There were brain MRI changes compatible with WD in $67 \%$ (6 out of 9 ) of patients with neurological symptoms, whereas only $33 \%$ (I out of 3 ) of patients with no neurological symptoms had radiological findings suggesting WD.

\section{Discussion}

WD is a highly heterogenic disorder ${ }^{5,6}$ with very unspecific symptoms at onset, ${ }^{4}$ sometimes making it difficult to promptly establish the diagnosis and thus delay- ing treatment. It is therefore important to have a better knowledge of WD patients' characteristics, attempting to find predictors of neurological involvement. To the best of our knowledge, this is the first published study aiming to deeply characterize a Portuguese population of patients with WD.

We found a female predominance in our sample $(71 \%, n=17)$, in contrast with a slight male predominance described in the literature. ${ }^{12-14}$ However, the median age at diagnosis ( 17 years) approached the typical peak prevalence age (between 20 and 40 years). ${ }^{12,15}$ Although the mean age at diagnosis for the neurological disease is described as 22 years ${ }^{15-17}$ and neurological manifestations usually develop later than hepatic presentation, ${ }^{18}$ that is not reflected in this sample, as median ages at diagnosis for patients with pure hepatic and neurological forms ( 16.5 and 16 years, respectively) did not differ significantly.

$A T P 7 B$ gene sequencing showed a great diversity of gene variants. Nevertheless, c.2123T $>C$ was the most frequent mutation in our sample, contrasting with the most frequent mutation in Europe (c.3207C>A). Yet, this might not be representative of our centre's population and certainly not of the entire Portuguese population due to the limited number of available gene sequencing.

Although the mixed hepatic and neurological form and pure hepatic form were the most common disease manifestations in our sample, $58 \%(n=14)$ of patients

Table 3. Clinical and laboratorial parameters at diagnosis and its correlation with neurological disease assessed with Mann-Whitney test and Fisher's exact test (statistical significance with p-value <0.05)

\begin{tabular}{|c|c|c|c|}
\hline Variables (at diagnosis) & $\begin{array}{l}\text { Patients with neurological } \\
\text { involvement }(n=14)\end{array}$ & $\begin{array}{l}\text { Patients without neurological } \\
\text { involvement }(n=10)\end{array}$ & $p$-value \\
\hline Age (years) & $29 \pm 25$ & $16.5 \pm 5$ & 0.06 \\
\hline Fibroscan ${ }^{\circledR}$ value (kPA) & $13.6 \pm 23$ & $4.4 \pm 0$ & 0.07 \\
\hline Serum copper $(\mu \mathrm{g} / \mathrm{d})$ & $25 \pm 34$ & $16 \pm 99$ & 0.75 \\
\hline 24 h urinary copper ( $\mu \mathrm{g} /$ day) & $122 \pm 571$ & $217 \pm 1233$ & 0.66 \\
\hline Serum ceruloplasmin (mg/dL) & $0.06 \pm 1.96$ & $0.06 \pm 1.98$ & 0.95 \\
\hline Copper in dry liver biopsy ( $\mu \mathrm{g} / \mathrm{g}$ of liver) & $876 \pm 0$ & $880 \pm 836$ & 1 \\
\hline Normal AST and ALT (n) & 11 & 0 & $<0.01^{*}$ \\
\hline Thrombocytopenia (n) & 10 & 5 & 0.22 \\
\hline Abnormal INR (n) & 4 & 4 & 0.67 \\
\hline Hypoalbuminemia (n) & 1 & 4 & 0.12 \\
\hline Kayser-Fleischer ring presente ( $n$ ) & 7 & 3 & 0.42 \\
\hline
\end{tabular}

*: significant p-value; INR: international normalized ratio. 
presented with neurological involvement. That is in line with an extremely variable reported prevalence of neurological manifestations in WD ranging from $5 \%$ to $65 \% .^{18}$

The triad of rigidity, bradykinesia, and tremor was the most common set of neurological signs, which is in agreement with the findings of previous studies. . $^{15,19,20}$ Of them, bradykinesia was more frequent in the younger patients, but with no statistical significance.

The presence of other diseases was an exclusive feature of I patient with neurological involvement and a remarkable prevalence of psychiatric disorders was observed. However, this represents a small proportion when all 24 patients are taken into account, as it is estimated that approximately half of all patients with WD have psychiatric problems. ${ }^{4}$

Regarding the treatment and posterior evolution of neurological symptoms, we found a deterioration of the neurological status in 3 of the II patients with available post-therapy status described in clinical records. Of them, 2 were treated with trientine (one of them also treated with zinc acetate and one of them with zinc acetate and penicillamine both in the past) and the other one was treated with zinc acetate and penicillamine. Worsening of neurological symptoms has been reported to occur with chelating agents and it was thought that this phenomenon occurred less frequently with trientine than with penicillamine. ${ }^{2}$ However, recent studies have demonstrated that both drugs have a similar risk of neurological deterioration in WD. ${ }^{8,10}$ Moreover, trientine has been linked to a $26 \%$ risk of neurological deterioration in WD. ${ }^{21}$ It is still important to mention that the number of patients with neurological symptoms who underwent treatment and had an available description of their neurological status post-therapy initiation was very limited $(n=I I)$, not allowing to establish statistically significant conclusions.

Of all symptomatic treatments used in this sample, levodopa/carbidopa seemed to be the one with the least advantage in improving neurological symptoms. Copper accumulation in the brain leads to dysfunction of basal ganglia and there are reports of striatal and presynaptic (nigrostriatal) dopaminergic lesions in patients with WD. ${ }^{22}$ This is in line with the use of levodopa/carbidopa to control extrapyramidal symptoms in WD, ${ }^{23}$ but we did not observe such a satisfactory result in this group of patients. It is known that dopaminergic treatment (both with levodopa and dopaminergic agonists) is not always effective in WD patients and shows a large interindividual difference. This may be due to several reasons, such as combined presynaptic and postsynaptic nigrostriatal deficits or concomitant involvement of other neurotransmitters like acetylcholine. ${ }^{24}$

Only normal serum AST and ALT levels at diagnosis correlated positively with the presence of neurological disease. This data is against the lack of correlation between hepatic status at diagnosis and neurological impairment observed in other studies. ${ }^{18,19}$ This might however be explained by two possible mechanisms: I) even though the CNS is initially protected for some years because of the blood-brain-barrier and thus WD patients with hepatic involvement are normally diagnosed at an earlier stage than those with neurological involvement, ${ }^{15,25}$ it is known that patients who develop neurological signs as the first WD manifestation show compensated liver cirrhosis that develops insidiously $13,18,19,26$ and there may already be some copper metabolism abnormalities affecting the CNS at this stage without abnormal blood hepatic tests; 2) WD also results in functional deficiencies of many enzymes that require copper as a cofactor and are important in neuronal metabolism and homeostasis, affecting the neurological phenotype in the disease. ${ }^{18,27,28}$

Finally, the presence of Kayser-Fleischer rings at diagnosis did not correlate with the presence of neurological disease in our sample. These rings are due to copper deposition on the surface of Descemet's membrane and endothelial cells. At least half of patients present with this sign and it appears when central nervous system (CNS) enters a saturated stage. However, the presence of Kayser-Fleischer rings is not exclusive from WD, because those rings are also found in patients with chronic cholestasis, as bile excretion is the main way of reducing copper concentration.'

This study has some limitations which need to be taken into account. First, it was a retrospective study, not allowing access to many variables which were not available or simply not registered previously. Second, the size of the sample was manifestly reduced because it was a single-centre study. Although we understand WD is a rare disease and it is not possible to gather a wide sample of patients, these two factors combined made it difficult to achieve statistical significance in almost all variables, which might show otherwise in a bigger sample. Also, the definition of neurological disease through neurological signs and symp- 
toms might be rather broad, as one patient with no neurological signs nor symptoms presented with MRI findings suggestive of WD, showing that there may be a spectrum of neurological involvement in this disorder that could be useful to study. Finally, the absence of treatment consensus regarding patients with neurological involvement from disease onset leads to treatment heterogeneity and thus hampers a retrospective comparison between treated patients in respect to treatment effectiveness and disease evolution.

\section{Conclusion}

We conclude that initial assessment of liver transaminase levels may help to identify WD patients who are more likely to develop neurological symptoms, alerting to the need for regular neurological evaluations. Although our study has shed light on the identification of possible clinical factors related to neurological involvement in WD, a prospective multi-centre study is necessary to better address other factors in the population of patients of WD, such as molecular characterization of gene mutations in Portugal and disease treatment in patients with neurological involvement (as there are still many unanswered questions regarding this particular issue).

\section{Responsabilidades Éticas}

Conflitos de Interesse: Os autores declaram a inexistência de conflitos de interesse na realização do presente trabalho.

Fontes de Financiamento: Não existiram fontes externas de financiamento para a realização deste artigo.

Confidencialidade dos Dados: Os autores declaram ter seguido os protocolos da sua instituição acerca da publicação dos dados de doentes.

Proteção de Pessoas e Animais: Os autores declaram que os procedimentos seguidos estavam de acordo com os regulamentos estabelecidos pelos responsáveis da Comissão de Investigação Clínica e Ética e de acordo com a Declaração de Helsínquia de 2013 da Associação Médica Mundial.

Proveniência e Revisão por Pares: Não comissionado; revisão externa por pares.

\section{Ethical Disclosures}

Conflicts of Interest: The authors have no conflicts of interest to declare.

Financing Support: This work has not received any contribution, grant or scholarship

Confidentiality of Data: The authors declare that they have followed the protocols of their work center on the publication of data from patients.

Protection of Human and Animal Subjects: The authors declare that the procedures were followed according to the regulations established by the Clinical Research and Ethics Committee and to the 2013 Helsinki Declaration of the World Medical Association.

Provenance and Peer Review: Not commissioned; externally peer reviewed.

\section{References / Referências}

1. Liu J, Luan J, Zhou X, Cui Y, Han J. Epidemiology, diagnosis and treatment of Wilson's disease. Intractable Rare Dis Res. 2017; 6:249-55. doi: 10.5582/irdr.2017.01057

2. Rodriguez-Castro KI, Hevia-Urrutia FJ, Sturniolo GC. Wilson's disease: a review of what we have learned. World J Hepatol.2015; 7:2859-70. doi: 10.4254/wjh.v7.i29.2859

3. Poujois A, Woimant F. Wilson's disease: a 2017 update. Clin Res Hepatol Gastroenterol. 2018; 42:512-20. doi: 10.1016/j. clinre.2018.03.007.

4. Hedera P. Update on the clinical management of Wilson's disease. Appl Clin Genet. 2017; 10:9-19. doi: 10.2147/ TACG.S79121.

5. Wu F, Wang J, Pu C, Qiao L, Jiang C. Wilson's disease: a comprehensive review of the molecular mechanisms. Int $\mathrm{J}$ Mol Sc. 2015; 16:6419-31. doi: 10.3390/ijms16036419.

6. Chang IJ, Hahn SH. The genetics of Wilson disease. Handb Clin Neurol. 2017; 142:19-34. doi: 10.1016/B978-0-44463625-6.00003-3.

7. Ralle M, Huster D, Vogt S, Schirrmeister W, Burkhead JL, Capps TR, et al. Wilson disease at a single cell level: intracellular copper trafficking activates compartment-specific responses in hepatocytes. J Biol Chem. 2010; 285:3087583. doi: 10.1074/jbc.M110.114447.

8. Weiss KH, Thurik F, Gotthardt DN, Schäfer M, Teufel U, Wiegand F, et al. Efficacy and safety of oral chelators in treatment of patients with Wilson disease. Clin Gastroenterol Hepatol. 2013; 11:1028-35. doi: 10.1016/j. cgh.2013.03.012.

9. Poujois A, Mikol J, Woimant F. Wilson disease: brain pathology. Handb Clin Neurol. 2017; 142:77-89. doi: 10.1016/ B978-0-444-63625-6.00008-2.

10. Litwin T, Dziezyc K, Karlinski M, Chabik G, Czepiel W, Członkowska A. Early neurological worsening in patients with Wilson's disease. J Neurol Sci. 2015; 355:162-7. doi: 10.1016/j.jns.2015.06.010.

11. European Association for Study of Liver. EASL Clinical Practice Guidelines: Wilson's disease. J Hepatol. 2012;56:67185. doi: 10.1016/j.jhep.2011.11.007

12. Poujois A, Woimant F, Samson S, Chaine P, Girardot-Tinant $\mathrm{N}$, Tuppin P. Characteristics and prevalence of Wilson's disease: A 2013 observational population-based study in France. Clin Res Hepatol Gastroenterol. 2018; 42:57-63. doi: 10.1016/j.clinre.2017.05.011.

13. Litwin T, Gromadzka G, Członkowska A. Gender differences in Wilson's disease. J Neurol Sci. 2012; 312:31-5. doi: 10.1016/j.jns.2011.08.028.

14. Lai CH, Tseng HF. Population-based epidemiologic study of Wilson's disease in Taiwan. Eur J Neurol. 2010; 17:830-3. doi: 10.1111/j.1468-1331.2009.02946.x.

15. Hefter H, Tezayak O, Rosenthal D. Long-term outcome of neurological Wilson's disease. Parkinsonism Relat Disord. 2018; 49:48-53. doi: 10.1016/j.parkreldis.2018.01.007.

16. Burke JF, Dayalu P, Nan B, Askari F, Brewer GJ, Lorincz MT. Prognostic significance of neurologic examination findings in Wilson disease. Parkinsonism Relat Disord. 2011; 17:55156. doi: 10.1016/j.parkreldis.2011.05.002.

17. Ghika J, Vingerhoets F, Maeder P, Borruat FX, Bogousslavsky J. Maladie de Wilson. EMC Neurol. 2004; 1:481-511. doi: 10.1016/j.emcn.2004.03.003.

18. Seo GH, Kim YM, Oh SH, Chung SJ, Choi IH, Kim GH, et al. Biochemical and molecular characterisation of neurological Wilson disease. J Med Genet. 2018; 55:587-93. doi: 10.1136/jmedgenet-2017-105214.

19. Członkowska A, Litwin T, Dziezyc K, Karlinski M, Bring J, Bjartmar C. Characteristics of a newly diagnosed Polish cohort of patients with neurological manifestations of Wilson disease evaluated with the Unified Wilson's Disease Rating Scale. BMC Neurol. 2018; 18:34. doi: 10.1186/s12883-018-1039-y.

20. Ferenci $P$, Członkowska A, Merle, Ferenc S, Gromadzka G, Yurdaydin C, et al. Late onset Wilson's disease. Gastroenterology. 2007; 132:1294-8. doi: 10.1053/j.gastro.2007.02.057. 
21. Brewer GJ, Askari F, Lorincz MT, Carlson M, Schilsky $M$, Kluin KJ, et al. Treatment of Wilson disease with ammonium tetrathiomolybdate: IV. Comparison of tetrathiomolybdate and trientine in a double-blind study of treatment of the neurologic presentation of Wilson disease. Arch Neurol. 2006; 63:521-7. doi: 10.1001/archneur.63.4.521.

22. Mueller A, Reuner $U$, Landis $B$, Kitzler $H$, Reichmann $H$, Hummel T. Extrapyramidal symptoms in Wilson's disease are associated with olfactory dysfunction. Mov Disord. 2006;21:1311-6. doi: 10.1002/mds.20989.

23. Aggarwal A, Bhatt M. The Pragmatic Treatment of Wilson's Disease. Mov Disord Clin Pract. 2014;1:14-23. Doi: 10.1002/mdc3.12003.

24. Litwin A, Dušek $P$, Członkowska A. Symptomatic treatment of neurologic symptoms in Wilson disease. Handb Clin Neurol. 2017;142:211-23. doi: 10.1016/B978-0-444-636256.00018-5.
25. Merle U, Schaefer M, Ferenci P, Stremmel W. Clinical presentations, diagnosis and long-term outcome of Wilson's disease: a cohort study. Gut. 2007; 56:115-20. doi: 10.1136/ gut.2005.087262.

26. Przybyłkowski A, Gromadzka G, Chabik G, Wierzchowska A, Litwin T, Członkowska A. Liver cirrhosis in patients newly diagnosed with neurological phenotype of Wilson's disease. Funct Neurol. 2014; 29:23-9. doi: 10.11138/ FNeur/2014.29.1.023.

27. Lutsenko S, Bhattacharjee A, Hubbard AL. Copper handling machinery of the brain. Metallomics. 2010; 2:596-608. doi: 10.1039/c0mt00006j.

28. Linder MC, Hazegh-Azam M. Copper biochemistry and molecular biology. Am J Clin Nutr. 1996; 63:797s-811s. doi: 10.1093/ajcn/63.5.797. 